\title{
NECROMARKETING AS ADVERTISING STRATEGY IN AMERICAN TELEVISION
}

Amiee J. Shelton ${ }^{7}$

\begin{abstract}
Significant research has been conducted regarding fear appeals, but little empirical evidence concerning death appeals is found. This study determined to what extent necromarketing exists in advertisements in American television. Through a content analysis of 1012 American television advertisements, this study found what product categories employ this marketing strategy and which consumer groups were targeted. Findings show that implicit necromarketing is a more commonly used marketing tactic than explicit necromarketing; the industries of entertainment promotions and insurance use necromarketing appeals more often than others, and necromarketing appeals were more heavily used during primetime. His study forms the base for future studies investigating the impact death has on purchase intentions.
\end{abstract}

Keywords: Necromarketing, Television, Marketing, Advertising, Death in Marketing, Promotion, Marketing Communication

\section{Introduction}

"The idea of death, the fear of it, haunts the human animal like nothing else: it is the mainspring of human activity-activity designed largely to avoid the fatality of death, to overcome it by denying it in some way that is the final destiny for man" [Becker, 1973, p. ix]. Death comes in many forms, sometimes by time, accident, disease, or intentional infliction by another human. Regardless of the method death occurs, mankind perceives death to be painful. Thus, death is the ultimate form of fear, and human behavior seeks to willfully ignore the inevitability of death [Becker, 1973].

Emotional appeals have been accepted for ages as being a great motivator for the consumers. Emotions are important to the advertising schematic, both to gain attention from consumers and to drive behavior. Regarding advertising appeals, the literature typically compares affect [emotion] to cognition, concluding that emotion influences decisions in the present whereas reason-based thinking [cognition] influences long-term decisions [Liberman et al., 2006]. However, presentation of emotion can be both concrete and abstract [Bulbul \& Menon, 2010]. Bulbul \& Menon [2010] propose that the "nature of an affective claim determines whether affect will be more influential for short- versus long-term decisions" [p. 177]. Concrete affect has more influence on behavioral "intentions relating to the shorter term, while abstract affect has more influence on behavioral intentions relating to the longer term" [Bulbul \& Menon, 2010, p. 177]. Therefore, the specific meaning of the emotional appeal determines how it will be used in judgment by the consumer [Tiedens and Linton, 2001].

Advertisements with controversial material have a positive impact on consumers' 
attention and ad awareness [Dahl, Frankenberger, and Manchanda, 2003]. Furthermore, emotional appeals represented concretely reveal consumers contextualize, subordinate, and link the message to the details and specifics of their situation. Alternatively, abstract emotional appeals are linked to more general impressions, the "gist" of an event or object. Bulbul \& Menon [2010], suggest that abstract affective appeals might work better for retirement products due to the longer-term perspective of consumers, whereas persuasive appeals for loyalty programs could be framed more abstractly "because by default such programs ask for long-term behavioral connections" [p. 177].

Strategic planning for advertising results in the "dominant mood" for the product, where the product's most important appeal is determined on a continuum between rational and emotional. For most products, the dominant mood remains consistent throughout all marketing communication efforts. The way emotion is used in marketing communication efforts has been studied. However, how death is presented regarding marketing strategy is missing from the literature, despite the fact that since 2009 , there has been a increase in the number of advertisements and public service announcements featuring death, tragedies, and illnesses [Wojciechowski, 2010].

Necromarketing [the marketing of death] is a construct of marketing which uses various established persuasive communication methods, but features situations and objects explicitly or implicated connected to death or parasites on death or tragedy in order to elicit an emotional attachment to the product, service, or cause being propagated [Wojciechowski \& Shelton, 2014]. While many studies have explored the impact fear appeals have on consumers, few studies have explored directly into the topic of necromarketing. The purpose of this study is to examine if implicit and explicit necromarketing exists in advertisements in American television advertisements, to quantify what industries, brands or products/services use necromarketing and to what extent, and ultimately which consumers were targeted. It is important to study the role necromarketing plays in American television advertisements for many reasons: ethical implications, primacy effects, the credibility of advertising, brand perceptions and cultural roots.

\section{Media Consumption}

Despite the number of channels available, or perhaps because of the numbers consumers have to choose from brands are challenged still with the task of breaking through the clutter. According to Media Dynamics [2014], "the number of ads that adults are now exposed to across all five media [TV, radio, Internet, newspapers and magazines] is about 360 per day." This clutter or "noise" is causing many to become desensitized to traditional advertising strategies. Consumers are exposed to approximately 360 persuasive messages, yet only about 150 advertisements get consumers to pay attention. Far fewer make a strong enough impact to be recalled, make an impression, or ultimately, lead to the desired behavior [Johnson 2014].

Additionally, an increasing number of "consumers are more likely to declare independence from advertising, claiming their consumption behavior and decision-making processes are not due to advertising" [Petrova, 2011, p. 79]. Therefore, advertising must get consumers emotionally motivated to investigate and ultimately to buy the advertised product or service. Using death as a strategy not only gains attention but can also influence purchase habits through the fear the idea of death brings to consumers.

There are a number of fears that are attributed to the idea of death, and "researchers have suggested that the fear of death is actually a multi-dimensional concept" [Moore \& Williamson, 2003, p. 3]. There have been eight dimensions of the fear of death distinguished [Hoelter and Hoelter, 1978]. These include 1] fear of the dying process, 2] fear of premature death, 3] fear for significant others, 4] phobic fear of death, 5] fear of 


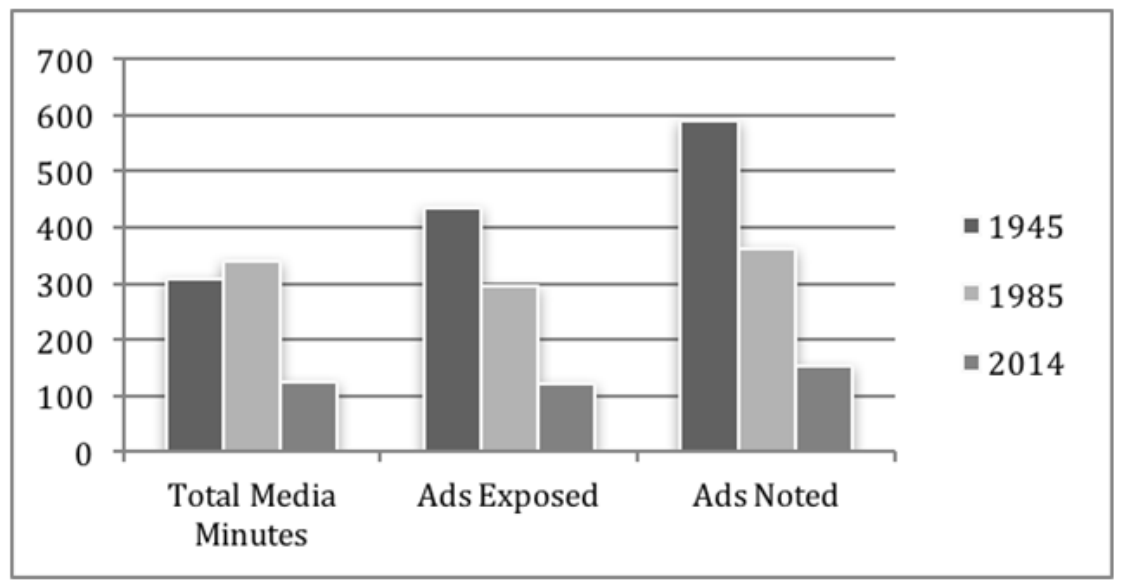

Ads Exposed are ads that can be seen / heard

Ads Noted attracted the audience's full attention for a few seconds or more

Source: 9/14 Media Dynamics, Inc

\section{Exhibit 1: Average Adult's Daily Media \& Ad Exposure}

being destroyed, 6] fear of the body after death, 7] fear of the unknown, and 8] fear of the dead [Hoelter and Hoelter, 1978]. Additionally, Florian and Mikulincer [1993] argue that intrapersonal, interpersonal and transpersonal components are primary undercurrents for the fear of death. Intrapersonal components are "related to the impact of death on the mind and body, which include fears of loss of fulfillment of personal goals and fear of the body's annihilation" [Florian \& Mikulincer, as cited in Moore \& Williamson, 2003, p. 3]. An interpersonal component is related to the effect death has on inter-personal relationships while a transpersonal component concerns fears about the transcendental self, such as the "punishment after death" [Florian \& Mikulincer, as cited in Moore \& Williamson, 2003, p. 3].

As the fear of death is quite complex, some authors suggest using the term "death anxiety" to describe the amorphous set of feelings that thinking about death can arouse [Schultz, 1979]. The complexity around death, and the number of fears produced by thinking about it, suggests that such fears could be either natural or social constructs. The most common view, historically speaking is that the fear of death is innate to humans. Moore \& Williamson [2003] argue humans spend their life avoiding death, and "that the underlying terror of death is what drives most of the human endeavor" [p. 3]. Therefore, many conclude that the fear of death is a universal and natural response to dying, specifically in view of all the attempts of biological organisms to preserve life [Moore \& Williamson, 2003].

\section{Emotion as Persuasion}

The emotion of fear has been argued to evolve as a mechanism to protect humans from life-threatening situations, and that is reflected in the evolutionary primacy of the brain's reasoning facilities. The area of the brain that processes perceptions and thoughts and tags them with "fear" is the amygdala. Like the neocortex, where conscious awareness is located, the "almond-shaped" bundle of neurons awareness is near the center of the brain. Thus, the emptions elicited by the dual process of Necromarketing motivate consumer's behavior towards self-interest and the interest of those within our sphere of care or concern [Begley, 2007]. The emotions of fear lead us to protect our family and ourselves. Overall, "the evolutionary primacy of the brain's fear circuitry makes it more powerful than the brain's reasoning faculties" [Begley, 2007, para. 6]. Consequently, fear can be easily stroked and can be irrational and not subject to reason [Maren, 2008]. Therefore, during a scary experience, relationship between a consumer and a brand can improve. When people feel fear, brands and affiliations provide 
that link and make people feel better [Dunn \& Hoegg, 2014]. While studies also reveal that participants who saw advertisements with morality reminders had more negative attitudes towards the advertisement, these same consumers had increased purchase intent of the product advertised [Das, Duiven, Arendsen, and Vermeulen, 2014]. These finding aligns with Dar-Nimrod's [2012] findings that when consumers are faced with the inevitability of their own death, they experience a fear, mostly unconscious fear, that they suppress by pursuing wealth and buying products to reinforce a materialistic worldview [Das, et al., 2014].

Similar to this finding, Cooper, Goldenberg and Arndt [2014] found that those who were primed with messages specifically using death as a fear appeal reported that they were more likely to change their behavior than those who were exposed to messages with a general fear appeal, but not suggesting death. Therefore, there is an established body of research supporting the use of mortality reminders in fear appeals, as there is a significant increase in intended behavioral change and purchasing habits.

Fear has further effects on consumers than just encouraging materialism. Dunn and Hoegg [2014] found that fear appeals have the ability to facilitate emotional brand attachment. When consumers view fearful advertisements, they seek out affiliation with others to help cope through the uncomfortable experience, and in the case of advertisements, viewers seek affiliation with brands [Dunn \& Hoegg, 2014]. This finding suggests that consumers become emotionally attached to products that are advertised to them in a fearful way. Therefore, the myriad of marketing communications efforts in an array of product categories [political candidates, health care, non-profit, consumer products] is strategically produced to play on these human fears. With this strategy, communicators are creating a perpetuate state of fear in consumers to keep them submissive to advertising messages [Becker, 1974, p. 14].

\section{Necromarketing}

Necromarketing is a viable marketing construct, as death depictions are used paradoxically as death scares and attracts people as the same time [Walter, Littlewood, \& Pickering, 1995]. Wojciechowski and Shelton [2014] defined necromarketing as a dual process construct involving two routes of persuasion, similar to both the Heuristic-Systematic Model of Information Processing [HSM] and the Elaboration Likelihood Model [ELM]. As with the HSM and ELM models, which examines heuristic and systematics processing and central and peripheral route of processing respectively,

Necromarketing discusses explicit and implicit processing [Exhibit 1]. Where $\mathrm{Nec}-$ romarketing differs from both ELM and HSM is the level of processing. With both of these established models, the argument [or persuasive message] is evaluated, and a determination must be made if the argument is strong or weak in order to classify the method into the appropriate process. Necromarketing affects consumers on a more basic level, causing a block on conscious and rational thinking when evaluating brands. This occurs because nothing is more uncomfortable than fear [Wojciechowski \& Shelton, 2014, p 93].

Regardless of the level of processing [explicit or implicit] used in Necromarketing, the idea of death causes fear. "Fear of death is one of the inclinations people have that lead them towards death defying behavior" and most of human inclinations people have that lead them towards death defying behavior do not stem from calculations [Becker, 1973, p. 11].

Explicit Necromarketing deals with displaying catastrophes, misfortunes and deaths in their pure, direct form. A direct death reference or display includes the depiction of corpses, autopsy, death, illness, or bad luck and undertaking service. The explicit form of Necromarketing is a valued and heavily used method in marketing communications because of the inevitability of death for mankind. Perhaps it is for this reason 


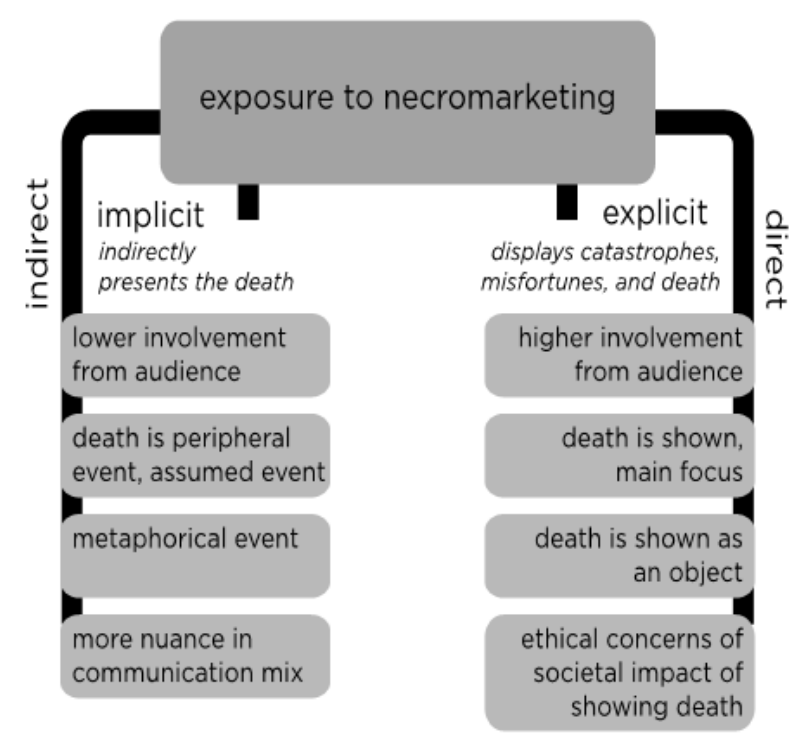

Adapted from "Necromarketing in Advertising," by

L. Wojciechowski and A, Shelton, 2014, Studia

Ekonomiczne 01/2014; NR205(Marketing

Communication Special Ed.):91-97.

\section{Exhibit 2: Dual Routes in Necromarketing}

alone, that the idea of death fascinates the human race. Explicit Necromarketing creates an immediate connection between the brand and the consumer, in part because emotions dictate that connection. Feelings lead to emotions and emotions connect people; tragedy touches people, creating greater sensitivity at that moment. Thus, the explicit form of Necromarketing has a profound effect on the human conscious.

Fear can be triggered powerfully not by wordy arguments but simply by images of death. This is because fear is a primitive nature, and that feeds directly into the brain's emotion regions. Although, words that evoke images of death over words that give abstractions are also powerful triggers of fear. Therefore, even something as seemingly innocuous as passing a funeral procession reminds consumers of the inevitability of death. To overcome this fear, people "go to ground" psychologically [Begley, 2010]. Therefore, consumers become more committed to brands and identify more strongly with brands and products that are enduring. When consumers are explicitly reminded with their own inevitable death, they expressed greater support for the products that confronted death other those that did not bring up morality at all [Begley, 2010].

Explicit processing often uses direct fear appeals. Fear appeals are composed of three main concepts: fear, threat, and perceived efficacy. "Fear is an emotion that is usually accompanied by heightened physiological arousal. Threat is an external stimulus that creates a perception in message receivers that they are susceptible to some negative situation or outcome;" whereas "perceived efficacy is a person's belief that message recommendations can be implemented and will effectively reduce the threat depicted in the message" [Gore et al., 1998, 36]. Explicit forms of necromarketing are effective because they contain direct portrayal of death as well as high levels of threat and efficacy. In this appeal, the message contains a meaningful threat or important problem as well as a specific directed action that an individual can take to reduce the threat or problem [Witte and Allen, 2000].

Implicit Necromarketing, in the other hand, is the indirect presentation of death, working with symbols and pictures relating to death. The indirect presentation, however, does not limit the impact on the consumer. The implicit route works by attaching to already present human fears and insecurities about the inevitability of death. Working 
on the subconscious, the implicit route of Necromarketing could be thought of as a "softer" sell than the explicit route, but no less effective. Greenburg [2004] found subliminal reminders of death were effective in branding. An example of indirect fear appeals could be regarding advertisements that attempt to motivate people to help others in danger.

Fear resides in individuals, rather than in message content [Denzin, 1984]. Therefore, messages that are framed with precautionary or reassurance information rather than overt images of death to arouse fear, are likely to have the greatest impact on behavior. This is important especially given the fact that in some, overt fear may inhibit action. Thus, the implicit route of necromarketing is showing death with a degree of finesse. Studies have shown that the use of fear is most effective "when used as a scalpel rather than a cudgel" by stoking audience's anxieties instead of inflaming them [Begley, 2010, p. 4]. Implicit Necromarketing also serves up death by showing symbols identified with death, such as a skeleton, gravestone, or a coffin.

\section{Fear in Advertising}

While humor is used in necromarketing to present death, fear appeals are the common staple in necromarketing strategy, either through the explicit or implicit route. Fear often evokes the fight or flight response, and more often than the flight response is the first reaction. Humans often unconsciously flee back to their comfort zone. When the path to this comfort zone is murky, humans are likely to follow any illumination back to the path. This is why, in part, marketers use fear as often as they can. The basic strategy is that a scenario is constructed to evoke a sense of fear, and a solution-a path back to the comfort zone-is provided entailing the use of specific products or services. Therefore, messages concerning death are salient to consumers, and can precipitate forms of materialism [Urien \& Kilbourne, 2008].

Modern western society is characterized as death defying [Barry \& Yuill, 2012]. Death defying implies that the discussion of death, or the topic of dying or death in general, is silenced in polite conversation. Thus, when messages are disseminated concerning the topic of death, people find are confronted with cognitive dissonance, and seek consistency in their beliefs and attitudes in the situation. The use of fear appeals inherent in necromarketing are built from a foundation of various communication, marketing and psychological theories, providing a reason why usage is so widespread Most notably, the Terror Management Theory [TMT], and the Protection Motivation Theory [PMT] underscore death-marketing efforts.

Terror Management Theory [TMT] posits that humans have the cognitively capacity to be self-aware and instinctively learns towards self-preservation. This awareness allows humans to be aware of death. This awareness or understanding of death and the instinctive drive for self-preservation engenders a vast potential for terror in humans. To quell the terror that comes from death, humans invest in cultural belief systems [or worldviews] that infuse life with meaning. Therefore, strategic advertising efforts depict common worldviews to engage consumers with a brand in order to provide meaning to individual lives. Materialism is one human behavior seeks to lessen the impact of fear. After the World Trade Center tragedy, "Americans had to come to terms with death saliency that was subtly present in the fringes of their consciousness" [Urien \& Kilbourne, 2008 , p. 410]; therefore, Americans "started buying more houses, cars, electrical appliances, furniture, etc. This resulted in an increase in annual consumer spending of $6 \%$ between October and December of 2001" [Arndt et al., 2004b, p. 410].

Another theory, the Protection Motivation Theory [PMT] proposes that mankind protects themselves based on four factors: the perceived severity of a threatening event, the perceived probability of the occurrence [or vulnerability], the efficacy of the recommended preventive behavior, and the perceived self-efficacy [Rogers, 1983]. 
Therefore, both the threat appraisal and coping appraisal affects the protection motivation. The threat appraisal assesses the severity of the situation and examines how serious the situation is whereas the coping appraisal is how one responds to the situation. Advertising efforts play on this protection motivation by providing an answer to the fearful situation at hand. While there are many goals of marketing efforts, the ultimate goal of any marketing effort are to increase desired behavior and to "own" the market [McKenna, 1990]. Therefore, consumerism is on the minds of marketers during all efforts, most notably when being used as a strategy to guide consumers down the path towards safety.

Choosing which necromarketing appeal to use in an advertising effort comes down to three principles: "prevailing deliberation, thorough planning and emphasizing the creative side" [Krajčovič, 2015, p. 28]. With these principles in mind, it is prudent to mention that while necromarketing may use shock as a strategic communication tool in advertisement, shock is not a requirement. This is an important distinction, as studies have found that using shock techniques are found to be ineffective in advertisements [Urwin \& Ventor, 2014]. In fact, shock ads make no difference in terms of memory recall, and "no matter what gender, personal identity or religion, shock advertising appears to be ineffective, dull, unenjoyable and unpleasant" [Urwin \& Ventor, 2004, p. 212]. With shock, "people either do not remember anything at all with regards to the advertisement or only remember the imagery displayed" therefore brand positioning is not achieved because consumers are unable to remember the brand in question [Urwin \& Ventor, 2004 , p. 212]. Where necromarketing is involved, ads using either explicit or implicit appeals are able to break through the myriad of messages and make a connection with consumers. This is due to the fact that death is the "most universal common," the "ground of a universal community of which oneself is an ineluctable member" [Bamyeh, 2007, p.4].

\section{Research Questions}

Petty and Cacioppo's theory of persuasion explaining that fear appeals are more effective for a high involvement product than for a low involvement product guided us in our hypotheses. Furthermore, we based our hypotheses on the idea that fear is a basic emotion. Based on earlier findings regarding fear appeals in advertisements, the current study investigated advertisements [paid space] in American television, and with an understanding of American cultural practices, this study specifically investigated the following hypotheses:

$\mathrm{H} 1$ : Implicit necromarketing will be a more commonly used marketing tactic than explicit necromarketing;

$\mathrm{H} 2$ : The industries of insurance companies, and entertainment promotions will use necromarketing appeals more often then other product categories.

Because no previous research appears to have analyzed American television advertisements for necromarketing, the following research questions were also posed:

Q1: To what extent are explicit and implicit necromarketing appeals found in advertisements in American television?

Q2: Which type of necromarketing is used more in advertisements?

Q3: What industries use necromarketing the most?

Q4: Who do advertisers target with necromarketing?

\section{Methodology}

This study takes a quantitative approach to measuring necromarketing efforts in American primetime television programming. The method of content analysis was determined prudent as it allows researcher to collect a wide variety of data throughout 
any range of time, and is non-intrusive [Macnamara, 2006]. Therefore, researchers were able to examine a large sample of shows for multiple periods of time. Further support for the method of content analysis stems from the Cognitive Social Learning Theory [Bandura, 1986], which states that mass media [in particular television] has the power to reflect behavior and social attitudes that viewers observe, retain, and learn from. Thus, the Cognitive Social Learning Theory underpins any discussion about the impact of television content, including advertising, has on society.

The design of the research has as its underpinnings the idea of message system analysis, as introduced by George Gerbner. Message system analysis, as defined for this study comes from Gerbner's "Violence Profile" [1980]. Gerbners' approach was content analyses. For his studies, Gerbner created specific definitions of violence to determine whether an act was counted. To accurately code necromarketing, categories were created that mirror the dual process construct involving two routes of persuasion: explicit and implicit. This study was carried out on convenience sample of American television advertisements. Implicit necromarketing was coded when researchers saw indirect presentation of death, specifically regarding symbols and pictures referring to death. Examples of implicit necromarketing would be a cemetery, coffin, or angel; whereas explicit necromarketing displayed catastrophes, misfortunes and deaths in their pure, direct form. A direct death reference or display includes the depiction of corpses, autopsy, or death. Other coded variables included: the network, the time the show aired, and product category of the advertisement.

\section{Category Construction}

Regarding network, four broadcast networks were determined to be prudent to investigate [ABC, CBS, NBC, and FOX]. These four represent the largest broadcast television networks in the United States. While ABC, CBS and NBC traditionally are considered the big three [due to ratings, time on the air, programming hours], Fox has just about the same household reach percentage as the Big Three, and is therefore often considered a peer to $A B C, N B C$, and $C B S$ since it has also achieved equal or better ratings since the late 1990s. Most media outlets now include Fox in what they refer to as the "Big Four" television networks. Times varied across day-parts, and chosen using a convenience sampling method. Program promotions, while not advertising because they are not paid [and are therefore excluded from Kantar's advertising sponsor categories], were included in this study to be able to better understand what consumer groups were being targeted by necromarketing appeals.

The product category was determined by investigating the top product categories by spending in the United States. This list is populated quarterly by the highest levels of ad spending in various media. The top product categories across multiple quarters [with equal variance assumed] were as follows:

- Food [fast food, grocery stories, etc.]

- Baby/Children

- Department Stores

- Drinks

- Technology

- Pharmaceutical

- Insurance

- Automobiles

- Motion Pictures

- Network Promos

- Beauty 
- Other

In addition, coders noted the mode of persuasion used in the advertisement. These modes of persuasion [often referred to as rhetorical strategies or rhetorical appeals] are used to classify the speaker's appeal to the audience. To this end, logos [appeals to reason], ethos [appeals to consumer's character] and pathos [using emotion] were coded for each advertisement that used necromarketing as a strategy in the message.

The unit of analysis for this study was necromarketing and the vehicle of inspection was television advertisements airing during composite week of November 10 through November 16, 2015. The universe of this study consisted of any advertisement that aired during the television show.

\section{Encoder Reliability}

Multiple coders analyzed each advertisement. To increase reliability, these coders were trained in order to accurately understand and code each instance of visual and verbal depictions of civic virtue as defined by the researcher. A pilot test was conducted to establish encoder reliability before the start of the study. The coders watched television advertisements from 2013, which therefore were not included in this study. The range of reliability coefficients ranged from .75 to .97 , with the overall reliability score .90 using Cohen's Kappa.

Each coder used a video monitor to view each advertisement and had the coding sheet in front of them. Coders used a remote control to pause the program while marking the coding sheet. In some cases, a DVR was used to record the programming for a specific time slot during the day. Each show resulted in a new coding sheet.

\section{Findings}

After collecting data, and coding it into SPSS, we were able to run simple statistical tests to describe the results. Over all we coded 40 television shows, resulting in 1012 television advertisements for a total of 125 instances of necromarketing. Advertisements were sampled from a variety of product categories. As researchers first coded each commercial based on product category, and secondarily by type of necromarketing, this study has wide appeal to anyone investigating the product type advertised in American television, by day, time and network. Figure 1 shows the distribution of advertising by product category. Only the seven most populated categories were reported.

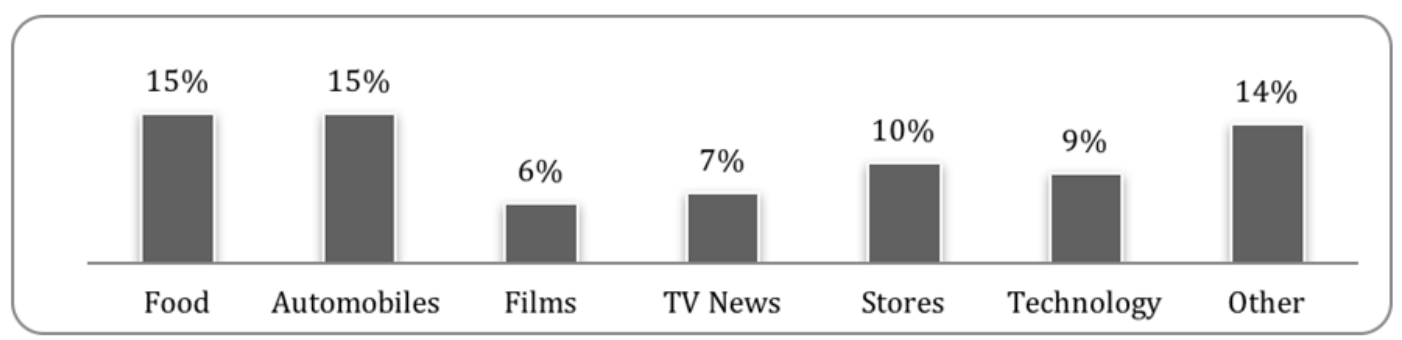

Figure 1: Primary Product Categories

As shown in Figure 2, both types of Necromarketing were found as marketing strategies in American advertising, although implicit necromarketing was used more often [9\%] as compared explicit necromarketing [2\%]. Only $1 \%$ of advertisements $[\mathrm{N}=$ 1012] portrayed both implicit and explicit necromarketing. 


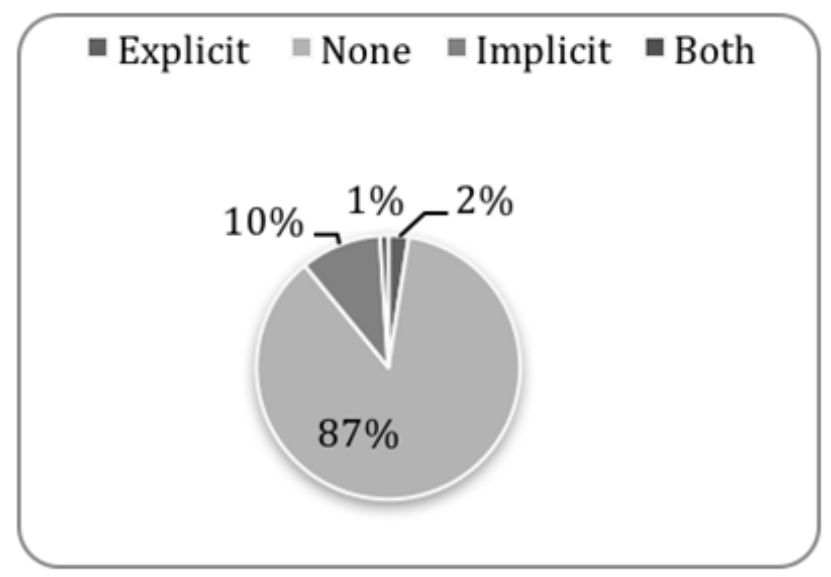

Figure 2: Types of Necromarketing

An independent samples t-test, was conducted to compare the product category mean scores to the advertisements that used implicit necromarketing as a strategy and those that did not. There was a statistical significance found $[M=8.47, S D=3.78$; $M$ 6.39, SD = 3.78]. While this analysis showed us what was already intuitively known by looking at the frequency breakdown [Table 1] it allowed researchers to combine create a new variable by combining the categories of implicit and explicit necromarketing, enabling us to pinpoint which product categories had the statistical difference by conducting a one-way anova.

\begin{tabular}{|l|r|r|r|r|r|r|}
\hline \multicolumn{7}{|c|}{ Necromarketing Per Product Category } \\
\hline \multirow{2}{*}{ Categories } & \multicolumn{2}{|c|}{ Implicit } & \multicolumn{2}{c|}{ Explicit } & \multicolumn{2}{c|}{ None } \\
\cline { 2 - 8 } & Frequency & Percent & Frequency & Percent & Frequency & Percent \\
\hline Insurance & 0 & - & 5 & $1 \%$ & 34 & $87 \%$ \\
\hline Film & 21 & $37 \%$ & 4 & $1 \%$ & 32 & $56 \%$ \\
\hline News Promotions & 24 & $36 \%$ & 12 & $1 \%$ & 28 & $43 \%$ \\
\hline Programming & 31 & $25 \%$ & 11 & $1 \%$ & 79 & $65 \%$ \\
\hline Programming & 31 & $25 \%$ & 11 & $1 \%$ & 79 & $65 \%$ \\
\hline
\end{tabular}

Table 1: Necromarketing Per Product Category

A one-way between subject analysis of variance was conducted with the newly coded variable to explore the type of necromarketing used in advertising and the product category, as measured by Nielsen. Subjects were divided into four categories according to the type of necromarketing, [Group 1: Explicit, Group 2: None, Group 3: Implicit, Group 4: both]. After running the test, statistical differences were found at the $p<$ .05 level in necromarketing scores for the four categories $[F=10.1, p=.000]$ showing that the advertisements in the product category of insurance $[M=5.91, S D=3.74]$ and motion pictures [M=8.34, SD $=2.47]$. While both categories had had instances of necromarketing, there were significant different in the type of necromarketing used, in that implicit necromarketing was the most prevalent in the product categories.

To investigate if the type of necromarketing used by communicators differed based on product category/industry, we ran non-parametric statistics, specifically in the form of a Chi- Square test of independence. The test [with Yates Continuity Correction] indicated a statically significant association between product category and necromarketing, $\mathrm{X} 2[33, \mathrm{n}=1009]=.26, \mathrm{p}=.000, \mathrm{phi}=.4$. The effect size is important to note. Using the Cramer's $V$, which takes into account degrees of freedom for tables larger then a 2 $X 2$ [in this case it was a $4 \times 12$ ], we removed one case from each the row [12-1] and column [5-1]. Using the smaller value of three [C-1 =3], we determined that the effect size was moderate to large [Cramer's $\mathrm{V}=.26$ ]. 
After running a cross tabulation of data, the results provided evidence concerning what industry used necromarketing most often in the advertising efforts. Advertisements in the product categories of insurance, films, television network show and news promotions were found to have the greatest number of necromarketing appeals. Out of 281 advertisements in these five categories, there were 108 necromarketing appeals [4\%]. Table 1 shows the percentages of explicit and implicit found in each product category. However, important to note is that three of the four product categories featured both implicit and explicit appeals in television advertisements.

Cross tabulations reveal the time slots of 8:00pm, 8:30pm, 9:00pm, and 10:00pm had the most necromarketing featured.

\begin{tabular}{|l|r|r|r|r|r|r|r|r|}
\hline \multicolumn{8}{|c|}{ Necromarketing in Primetime } \\
\hline \multirow{2}{*}{ Types } & 8:00 PM & \multicolumn{2}{|c|}{$8: 30$ PM } & \multicolumn{2}{|c|}{$9: 00$ PM } & \multicolumn{2}{|c|}{$10: 00$ PM } \\
\cline { 2 - 9 } & Frequency & Percent & Frequency & Percent & Frequency & Percent & Frequency & Percent \\
\hline Implicit & 22 & $16 \%$ & 17 & $13 \%$ & 16 & $19 \%$ & 20 & $22 \%$ \\
\hline Explicit & 3 & $2 \%$ & 2 & $1 \%$ & 1 & $1 \%$ & 3 & $3 \%$ \\
\hline None & 110 & $81 \%$ & 114 & $86 \%$ & 66 & $80 \%$ & 67 & $74 \%$ \\
\hline Total & 135 & $100 \%$ & 133 & $100 \%$ & 83 & $100 \%$ & 90 & $100 \%$ \\
\hline
\end{tabular}

Table 2: Necromarketing in Primetime

Nineteen percent of all advertisements airing in these evening hours [primetime] on television [ $n=441$ ] featured necromarketing appeals with $89 \%$ of all necromarketing ads using implicit appeals. Furthermore, the late morning/afternoon time slots of 10:30am, 11:00am, 11:30am, and 2:00pm featured more necromarketing then other timeslots in that day part. Twenty-two percent of all advertisements coded for these day parts were found to contain necromarketing appeals [ $n=198]$, with $63 \%$ of all necromarketing advertisements being implicit. Tables two and three illustrates the total advertisements coded, and the percentage of advertisements found to be necromarketing in daytime and primetime television respectively.

\begin{tabular}{|l|r|r|r|r|r|r|r|r|}
\hline \multicolumn{8}{|c|}{ Necromarketing in Daytime } \\
\hline \multirow{2}{*}{ Types } & $10: 30$ AM & \multicolumn{2}{|c|}{$11: 00$ AM } & \multicolumn{2}{|c|}{$11: 30$ AM } & $2: 30$ PM \\
\cline { 2 - 10 } & Frequency & Percent & Frequency & Percent & Frequency & Percent & Frequency & Percent \\
\hline Implicit & 8 & $9 \%$ & 7 & $25 \%$ & 5 & $12 \%$ & 8 & $24 \%$ \\
\hline Explicit & 2 & $2 \%$ & 5 & $18 \%$ & 5 & $12 \%$ & 4 & $12 \%$ \\
\hline None & 84 & $89 \%$ & 16 & $57 \%$ & 33 & $76 \%$ & 21 & $64 \%$ \\
\hline Total & 94 & $100 \%$ & 28 & $100 \%$ & 43 & $100 \%$ & 33 & $100 \%$ \\
\hline
\end{tabular}

\section{Table 3: Necromarketing in Daytime}

When investigating which American television network featured necromarketing, we ran cross tabulation, which revealed that while all networks had advertising with necromarketing, NBC had 82 [17\%] explicit and implicit appeals in advertisements [n = 496], $71 \%$ [ $=58$ ] of which were implicit appeals. 


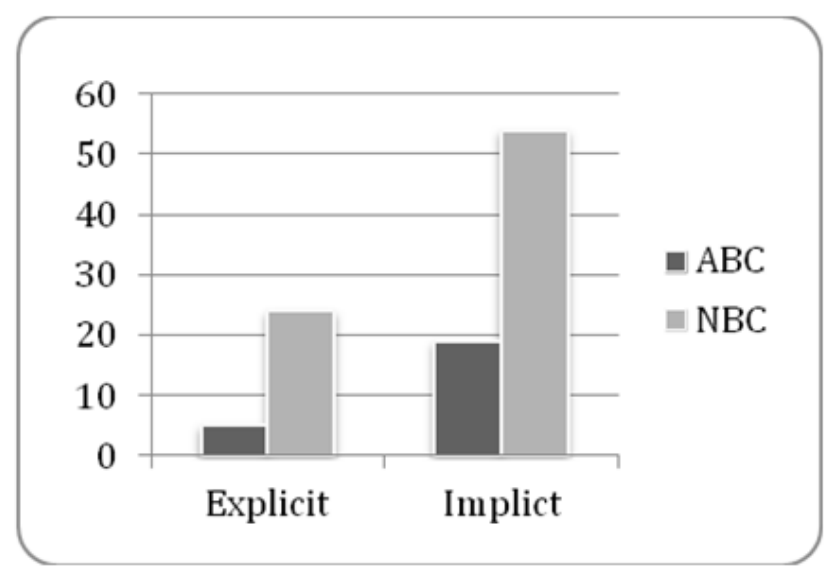

Figure 3: Necromarketing by Top Network

However, while the $A B C$ network had fewer advertisements coded in this study then other networks, the advertisements collected reveled that $20 \%$ of all ads [ $n=135$ ] featured necromarketing. To investigate if the television network differed regarding type of advertisements purchased by marketing departments, we ran a one-way between groups anova. We found a statistically significant difference at the $p<.05$ level between the networks CBS and NBC $[F=3.4, d f=3, p=.016]$. Despite reaching statistical significance, the actual difference in mean score between the groups was quite small. The effect size, calculated using eta squared was .01. Post Hoc comparisons using the Tukey HSD test, indicated that the mean score for $A B C$ was $[M=2.86, S D=.65], C B S$ was $[\mathrm{M}=3.14, \mathrm{DS}=.93]$ and $\mathrm{NBC}$ was $[\mathrm{M}=2.87, \mathrm{SD}=1.01]$, and $\mathrm{FOX}[\mathrm{M}=2.7, \mathrm{SD}=1.25]$. $A B C$ and FOX did not differ significantly from the other two.

In order to determine whom advertisers target with necromarketing, we conducted cross-tabulations to reveal which day of the week advertisers use necromarketing appeals. We found that Sunday, Tuesdays, and Fridays had a significantly higher amount of necromarketing appeals then Mondays, Wednesdays or Thursdays.

\begin{tabular}{|l|r|r|r|r|r|r|}
\hline \multirow{2}{*}{ Days } & \multicolumn{2}{|c|}{ Explicit } & \multicolumn{2}{c|}{ Implicit } & \multicolumn{2}{c|}{ Both } \\
\cline { 2 - 8 } & Frequency & Percent & Frequency & Percent & Frequency & Percent \\
\hline Sunday & 1 & $7 \%$ & 14 & $19 \%$ & 0 & - \\
\hline Monday & 2 & $13 \%$ & 17 & $24 \%$ & 0 & - \\
\hline Tuesday & 1 & $7 \%$ & 16 & $22 \%$ & 0 & - \\
\hline Wednesday & 0 & - & 1 & $1 \%$ & 0 & - \\
\hline Thursday & 2 & $13 \%$ & 7 & $10 \%$ & 2 & $50 \%$ \\
\hline Friday & 9 & $60 \%$ & 17 & $24 \%$ & 2 & $50 \%$ \\
\hline Totals & 15 & $100 \%$ & 72 & $100 \%$ & 4 & $100 \%$ \\
\hline
\end{tabular}

Table 4: Necromarketing Appeals by Day

\section{Discussion}

The proliferation of death in a myriad of marketing efforts can be attributed in some part to the proliferation of media channels and information sources, and due to modern death defying attitudes. To get consumers attention, advertising must be shocking and provoking. In fact, attention is so necessary in effective advertising, and the market is so competitive that attention is now often regarded as currency [Teixeira, 2014].

While previous studies have investigated fear appeals and their effect on consumers, very little research has been done on how advertisers market death. While only $13 \%$ 
percent of advertisements were considered necromarketing, we still were able to show that consumers are exposed to it in American television advertisements. Of the two methods of necromarketing, implicit necromarketing is used most often. This indirect approach means that advertisers tend to prefer to appeal to the subconscious than to use a shock approach.

Advertisements in the product categories of insurance, films, television network show and news and show promotions were found to have the greatest number of necromarketing appeals. Program promotions, while not advertising because they are not paid [and are therefore excluded from Kantar's advertising sponsor categories], were included in this study to be able to better understand what consumer groups were being targeted by necromarketing appeals. Based on the amount of advertising expenditures by product category, insurance, and films fall in the top five according to Kantar Media. Thus, if necromarketing is a strategy in these categories, the viewers have a greater likelihood of being exposed either through the explicit or implicit route. The findings regarding product categories, support the prediction that the industries of insurance companies, and entertainment promotions will use necromarketing appeals more often then others.

However, an interesting finding was that television shows promotions and news/ station promotions rated higher then another category. This was an interesting finding, as network promotions of its own content were not considered when investigating advertising expenditures. However, the use of necromarketing to promote primetime shows and newscasts is not surprising considering the amount of violence shown in American television shows [Shelton, 2007]. Furthermore, as one of the purposes in conducting this study was to define the consumer groups being targeted by necromarketing, these network promotions yield a great deal of information when cross tabulated with times and network.

Our assumption was that implicit necromarketing would be a more commonly used marketing tactic than explicit necromarketing was proven to be valid. Our assumptions that more necromarketing appeals would be found in primetime television, was also found to be valid. While there were a greater number of necromarketing appeals found in primetime, the daytime programs had nearly $6 \%$ of all ads having a necromarketing premise. Furthermore, we were able to pinpoint which time slots in primetime that had the highest occurrences of necromarketing, which was 20-21:00. This finding was important, as one of the goals of this research project was to determine who is targeted by necromarketing appeals. To make this determination, in addition to the time necromarketing was found in, we investigated which American television network aired more necromarketing advertisements, and what day they aired. Our findings revealed that while all networks had advertising with necromarketing, NBC and $A B C$ advertisements featured necromarketing more often. The days of Sunday, Tuesdays, and Fridays had a significantly higher amount of necromarketing appeals then Tuesdays, Wednesdays or Thursday [Figure 6]. These findings, combined with ratings information from Nielsen, show us that necromarketing is widely disseminated, exposing viewers from age's 1865 . The number of death related advertisements shown on NBC supports this statement, as NBC is the number one network with adults 18-49. Furthermore, six of the top 15 primetime shows air between 20-21:00, and four of the top 15 primetime shows air on NBC. Further support comes a Pew research report last year, that cited women ages 18-49 are the viewer most sought by advertisers during daytime TV. Thus we can say that necromarketing appeals in advertising are broadly, not narrowly targeted.

\section{Implications}

Overall these findings indicate that necromarketing is still a developing construct that isn't widely used by advertisers as of yet. This study is just the start of multiple opportunities for future research into the idea of necromarketing; to expand and 
better understand the concept and intricacies of both routes of persuasion. Further research should study the question of whether death marketing is ethically justified in and among various cultures. Further research should investigate specifically if explicit necromarketing is considered in the creative process in advertising planning.

Future research could also look at the amount implicit and explicit necromarketing and the industries that use them in other mediums such as magazines, newspapers or Internet advertisements. It would be interesting to see if there is a difference in necromarketing use in traditional media versus new media. This study combined with future research could aid advertisers in new tactics to persuade consumers to buy their products or services, create attachment to their brand and to stand out from competitors, specifically if research explores whether necromarketing makes a difference or not in terms of the effectiveness of ad. For example, future research could investigate, in addition to cultural difference, any difference between various age groups, ethnic or economic groups. Other studies experimental studies could measure behavior over time and what the effects of necromarketing may be to consumers over time. Other factors than can be researched are advertisement placement, in other words, does it make a difference where and in what context a consumer sees the advertisement. Furthermore, comparisons could be conducted investigating two different necromarketing appeals or the same product, where consumers would be asked to identify the most effective ad, which ad may portray the brand/message the best, and which overall leaves a lasting impression leading to increased purchase intention.

\section{Conclusion}

The purpose of this study was to set a baseline regarding the use of necromarketing in American televisions advertising. Through a content analysis of 1012 American television advertisements, this study determined to what extent implicit and explicit necromarketing exists in advertisements in American television. Additionally, this present study investigated what product categories employ necromarketing marketing as a strategy and ultimately which consumers are targeted. Findings show that implicit necromarketing is a more commonly used marketing tactic than explicit necromarketing; the industries of entertainment promotions and insurance use necromarketing appeals more often then others, and that necromarketing appeals were more heavily used during primetime. These results suggest many avenues for future experiments investigating the effects of necromarketing appeals on consumers and ethical standards.

\section{References}

ARNDT,J., SOLOMON T., KASSER, \& SHELDON K (2004), The Urge to splurge revisited: Further Reflections on Applying Terror Management Theory to Materialism and Consumer Behavior, Journal of Consumer Psychology, 14 (3), 225-29.

BANDURA A. (1986). Social foundations of thought and action: A social cognitive theory. Englewood Cliffs, NJ: Prentice- Hall, Inc.

BARRY A., \& YUILL, C. (2012). Understanding the Sociology of Health. An Introduction. London: Sage Publications Ltd.

BECKER E., (1973). The denial of death, New York: Simon \& Schuster.

BEGLEY S., (2007). The Roots of Fear. Newsweek, November 15 (2007). [online]. [2015-10-24]. Available at: www.newsweek.com/roots-fear-94379

BULBUL C. \& MENON, G. (2010). The Power of Emotional Appeals in Advertising The Influence of Concrete Versus Abstract Affect On Time-Dependent Decisions. Journal of Advertising Research. 50(2), p. 169-180.

COOPER D. \& GOLDWATER J., \& ARNDT, J. (2014). Perceived efficacy, conscious fear of death and intentions to tan: Not all fear appeals are created equal. British Journal of Health Psychology, 19(1), 1-15. 
DAHL D., FRANKENBERGER, K., \& MANCHANDA, R., (2003). Does It Pay to Shock? Reactions to Shocking and Nonshocking Advertising Content among University Students. Journal of Advertising Research, 268-280.

DAR-NIMROD I. (2012). Viewing death on television increases the appeal of advertised products. Journal of Social Psychology, 152(2), p 199-211.

DAS E., DUIVEN, R., ARENDSEN, J., \& VERMEULEN, I. (2014). Exploring killer ads: A terror management account of death in advertisements. Psychology and Marketing, 31(10), 828-842.

DENZIN N. (1984). On Understanding Emotion, San Francisco: Jossey-Bass.

DUNN J. \& HOEGG J. (2014). The Impact of Fear on Emotional Brand Attachment. Journal of Consumer Research, 41(1), 152-168.

FLORIAN V. \& MIKULINCE, M. (1993). The impact of death-risk experiences and religiosity on the fear of personal death: The case of Israeli soldiers in Lebanon. Omega, 26, 101-111.

GERBNER G. (1980). The Mainstreaming of America: Violence Profile No:11", Journal of Communication, 30(3), 10-29.

GORE P., MADHAVAN S., CURRY D. \& MCCLURG G. (1998). Persuasive messages, Marketing Health Services, 18(4), 32-43.

HOELTER J., \& HOELTER J. (1978). The Relationship Between Fear of Death and Anxiety. Journal of Psychology. 99, 225-26.

JOHNSON, S. (2014). New Research Sheds Light on Daily Ad Exposures. SJ Insights. [online: September, 29, 2014], https://sjinsights.net/2014/09/29/new-research-sheds-light-on-daily-ad-exposures/

KRAJČOVIČ P. (2015). Strategies in media planning. Communication Today, 6(2), p. 20-30.

LIBERMAN N., TROPE, Y., \& STEPHAN, E. (2006). "Psychological Distance." In Social Psychology: Handbook of Basic Principles (vol. 2). A. W. Kruglanski and E. T. Higgins, eds. New York: Guilford Press.

MACNAMARA J. (2005). Media content analysis: Its uses; benefit and best practice methodology. Asia Pacific Public Relations Journal, 6(1) 1-34.

MAREN S. (2008). Pavlovian fear conditioning as a behavioral assay for hippocampus and amygdala function: cautions and caveats. European Journal of Neuroscience. 28 (8), 1661-1666.

MCKENNA R. (1990). Marketing is everything. Harvard Business Review, 69 (1), 65-79.

MOORE C. \& WILLIAMSON, J. (2003). The Universal fear of death and the cultural response. [In:] Handbook of Death \& Dying. Thousand Oaks, CA : Sage. (p 3-14).

PETROVA I. (2011). Attitude to advertising as its social effect. Communication Today, 2 (2), p. 78-88.

ROGERS R. (1983). Cognitive and physiological processes in fear appeals and attitude change: A revised theory of protection motivation. In Cacioppo, J \& Petty, R. (ed.), Social Psychophysiology. New York: Guilford Press.

SCHULTZ R. (1979). Death anxiety: Intuitive and empirical perspectives. In L. BUGEN (Ed.), Death and Dying: Theory, research, and applications. Dubuque, IA: W.C. Brown. (p. 66-87).

SHELTON A. (2007). Frequency of violence in prime time dramas: An issue of gender, presented at the Eastern Communication Association Convention, Providence, R.I., April, 25-29.

TEIXERIA T. (2014). The Rising Cost of Consumer Attention: Why You Should Care, and What You Can Do About It. Working Paper 14-055 January 17. Available at: http://www.hbs.edu/faculty/Publication\%20Files/14055_2ef21e7e-7529-4864-b0f0-c64e4169e17f.pdf

TIEDENS L. \& LINTON S. (2001). Judgment Under Emotional Certainty and Uncertainty: The Effects of Specific Emotions on Information Processing. Journal of Personality and Social Psychology 81 (6), p. 973-988

URIEN B. \& KILBOURNE W. (2008). "On the Role of Materialism in the Relationship Between Death Anxiety and Quality of Life", in NA - Advances in Consumer Research 35. eds. Angela Y. Lee and Dilip Soman, Duluth, MN: Association for Consumer Research, (p. 409-415).

URWIN B. \& VENTER M. (2014). Shock Advertising: Not So Shocking Anymore. An Investigation among Generation Y. Mediterranean Journal of Social Sciences, 5(21), p. 203-214.

WALTER T. \& LITTLEWOOD J. \& PICKERING,M. (1995). Death in the news: public invigilation of private emotions. Sociology. 29(4), 579-596.

WITTE K. \& ALLEN M. (2000). A Meta-Analysis of Fear Appeals: Implications for Effective Public Health Campaigns. Health Education and Behavior, 27(5), 591-615.

WOJCIECHOWSKI L., \& SHELTON A. (2014). Necromarketing in Advertising. In BAJDAK, A. (ed.) Zeszyty Naukowe Uniwersytetu Ekonomicznego w Katowicach. Marketing Communications - Selected Issues. 205, 91- 
96.

WOJCIECHOWSKI L. (2010). Nekromarketing - niektoré aspekty jeho vymedzenia [in:] (KO)MÉDIÁ: sborník konferenčních príspěvků ze 4. ročníku mezinárodní konference, Zlín 21.-22.10.2009, UTB, Zlín. 